\title{
MASOQUISMO E MENSAGEM ENIGMÁTICA: PARA QUE RIMAR AMOR E DOR?
}

\author{
Fernando Cézar Bezerra de Andrade
}

\begin{abstract}
RESUMO. Discute-se neste trabalho um caso clínico cujo sintoma principal envolvia a realização de desejos masoquistas, expressos tanto em uma cena erótica específica, que envolve riscos, dor e humilhação, quanto em uma psicodinâmica fundada no culto ao sofrimento e dirigida à autodestruição, o que interferia em outras dimensões da vida do paciente: trabalho, formação intelectual e vínculos amorosos. Inicialmente, resume-se a metapsicologia do masoquismo na obra de Freud, bem como sua reavaliação da perspectiva da Teoria da Sedução Generalizada, formulada por Jean Laplanche. Em seguida, são discutidos a etiologia e o arranjo psíquico do paciente, bem como o processo psicanalítico, com seus principais momentos de atuação e de repetição das fantasias de sedução no contexto transferencial. A elaboração dos sintomas ao longo da análise é entendida como resultando de uma nova tradução para o enigma da sexualidade, formulado, sobretudo, pelas mensagens maternas e paternas, caracterizadas por traços de sadismo e perversão.
\end{abstract}

Palavras-chave: Psicanálise; caso clínico; masoquismo.

\section{MASOCHISM AND ENIGMATIC MESSAGE: WHY RHYME LOVE AND PAIN?}

\begin{abstract}
This article discusses a clinical case in which main symptom was the accomplishment of masochistic desires, expressed both in a specific erotic scene involving risks, pain and humiliation, and in the patient's psychodynamics, grounded on a cult of suffering and guided to self-destruction, which interfered in other dimensions of patient's life: work, intellectual and loving bonds. Initially, the metapsychology of masochism in Freud's work is summarized, as well as a reassessment promoted by the Theory of Generalized Seduction, formulated by Jean Laplanche. Next, the patient's etiology and his mental arrangement are discussed, as well as his psychoanalytic process, with the main moments of acting out and repeating the seduction fantasies in the context of transference. The formulation of symptoms during his psychoanalysis is understood as an effect of a new translation to his sexual enigmas, which were formulated especially from maternal and paternal messages, characterized by sadism and perversion.
\end{abstract}

Key words: Psychoanalysis; clinical case; masochism.

\section{MASOQUISMO Y MENSAJE ENIGMÁTICO: ¿POR QUÉ RIMAR AMOR Y DOLOR?}

RESUMEN. Se discute un caso clínico cuyo síntoma principal involucraba la realización de deseos masoquistas, expresados en una escena erótica específica, implicando riesgos, dolor y humillación, como en la psicodinámica basada en el culto al sufrimiento y dirigida a la autodestrucción, lo que interfería en otras dimensiones de la vida del paciente: su trabajo, formación intelectual y vínculos amorosos. Inicialmente, se resume la metapsicología del masoquismo en la obra de Freud, así como su reevaluación de la perspectiva de la Teoría de la Seducción Generalizada, formulada por Jean Laplanche. En seguida, se discute la etiología y la disposición mental del paciente y también el proceso psicoanalítico, con sus principales momentos de actuación y de repetición de las fantasías de seducción en el contexto transferencial. La elaboración de los síntomas a lo largo del análisis es interpretada como resultado de una nueva traducción por el enigma de la sexualidad, formulado, sobre todo, por los mensajes maternos y paternos, caracterizados por rasgos de sadismo y perversión.

Palabras-clave: Psicoanálisis; caso clínico; masoquismo.

Doutor em Educação pela Universidade Federal da Paraíba. Professor adjunto do Departamento de Fundamentação da EducaçãoCentro de Educação-Universidade Federal da Paraíba. Psicanalista da Sociedade Psicanalítica da Paraíba. 
Ainda que no samba de Monsueto Campos de Menezes e Arnaldo Passos, regravado em 1972 na voz de Caetano Veloso, "Mora na filosofia", o eu lírico recuse a saída masoquista, a pergunta evoca o problema do masoquismo, que, na teoria freudiana, foi submetido a revisões, acompanhando os caminhos da obra: como o prazer pode estar associado à dor, se, em tese, ambos são opostos?

Entende-se que, na verdade, o masoquismo é solução narcísica complementar e diametralmente oposta ao enigma da sexualidade, inconscientemente formulado por adultos de traços predominantemente sádicos e narcísicos.

Para demonstrar essa hipótese, discute-se um caso clínico conduzido pelo método psicanalítico, ao longo de quase uma década de atendimento com duas a três sessões semanais, em que a anamnese e a biografia do paciente servem de referências para o entendimento das causas dos sintomas. São apresentados, resumidamente, a queixa do paciente, seu mecanismo de atuação, o percurso da análise e seu termo: esses elementos são interpretados à luz do funcionamento do enquadre (e, nele, do manejo da transferência) como ocasião para a reinstalação do enigma da sexualidade e sua perlaboração em direção à superação do movimento autodestrutivo decorrente da associação entre amor e dor.

\section{EXPLICAÇÕES METAPSICOLÓGICAS PARA O MASOQUISMO: FREUD E LAPLANCHE}

O masoquismo recebe duas explicações na metapsicologia freudiana: num primeiro momento da teorização, ele é explicado como a reversão do sadismo sobre o próprio sujeito - exemplo de um dos destinos da pulsão, a reversão ao oposto (Freud, 1905/1974b, 1915/1974c, 1919/1974d). Nesse modelo, a agressividade era associada à própria atividade e à vida, pondo-se também, na fantasia, a serviço do narcisismo. Já num segundo momento, o masoquismo é pressuposto como originário, como efeito primário do ataque das pulsões de morte contra o eu, contrabalançado por Eros, que se opõe a Tânatos no contexto da segunda teoria das pulsões (Freud, 1920/1974e, 1924/1974f).

De acordo com essa última formulação, a agressividade deixa de ser interpretada como vital e ganha um caráter mortífero, de modo que o masoquismo já não mais aparece como uma saída secundária ao sadismo (como na primeira argumentação), mas como um sinalizador dos efeitos das pulsões de morte, postuladas com o estatuto de axiomas originários, naturais e irredutíveis. $\mathrm{O}$ masoquismo passa a ser pressuposto entendido como “prazer no sofrimento" (Freud, 1924/1974f, p. 203). A partir desse masoquismo erógeno, desenvolve-se uma tríade completada pelo masoquismo feminino (fantasias erógenas passivas) e pelo masoquismo moral (a culpa inconsciente).

A primeira teoria freudiana sobre a origem da sexualidade continha em si um paradigma epistemológico pelo qual a origem e a natureza do inconsciente eram pela sedução sexual da criança, futura histérica, por um adulto perverso. Tendo essa teoria restrita (Laplanche, 1988a, 1987/1992), abandonada por Freud (1897/1974a), mais e mais ele invoca premissas biológicas para manter sua psicodinâmica dualista, a despeito - e por causa - dos problemas epistemológicos em sua teoria, gerados pela gradual modificação na forma pela qual concebia o inconsciente. Nesse processo, a metapsicologia do masoquismo - como, de resto, em maior ou menor grau, toda a teoria freudiana - sofreu impactos da preponderância do biológico — representados em grau máximo pela segunda teoria das pulsões, trazida à luz em 1920.

Ora, a interpretação laplancheana supõe, quanto ao masoquismo, que ele desenvolve e consagra a passividade original de todo sujeito humano. Recusando Tânatos como um avatar não-sexual das pulsões (Laplanche, 1988b), o masoquismo é reposto no quadro das manifestações da sexualidade, no que ela tem de mais originário: a passividade que caracteriza a posição psíquica da criança diante das mensagens enigmáticas (Laplanche, 1992/2008b) constituídas no cenário da situação antropológica fundamental (doravante SAF).

O masoquismo, no contexto da Teoria da Sedução Generalizada, é interpretado como uma hipérbole da passividade infantil: suas fantasias eróticas são esforços de responder a um enigma anterior e mais profundo - o da sexualidade como um todo. Essa constatação remete, inicialmente, à consciência de que cada masoquismo é único, individual; e ao reconhecimento de que o masoquismo consiste em resposta, suficientemente organizada, a um imperativo interior provindo do ataque pulsional ao eu. Nessa direção, igualmente à primeira teoria freudiana, é postulado num segundo tempo psíquico, no tempo do après-coup.

Serão, portanto, as formas pelas quais esse eu responderá aos enigmas que decidirão boa parte dos destinos do erotismo - sendo o masoquismo uma delas, na qual, paradoxalmente, é pela passividade e submissão que uma autonomia, de traços fortemente narcísicos, manifesta-se. O prazer reside não na dor, mas na capacidade de suportá-la, tanto para sobreviver psiquicamente a quadros de privação e maus tratos 
quanto para negar a dependência em relação àquele que faz sofrer.

\section{O PRIMEIRO TEMPO DUMA ANÁLISE}

Gregório, um homem por volta dos 22 anos, procurou análise em 1992, por recomendação de outro profissional que cuidava de sua saúde física: vivia muito tenso, com dores nas costas que o impediam de produzir mais e melhor em seu trabalho. "Parecia que levava uma surra todo dia”, queixou-se inicialmente, numa metáfora que passou a fazer todo sentido depois. Além disso, acrescentou sua dificuldade em estabelecer e manter relacionamentos amorosos e sociais, de sentir-se à vontade com pessoas em geral e, em particular, no ambiente de trabalho, onde se sentia sempre explorado e humilhado. Também logo se declarou homossexual.

As queixas foram seguidas de um resumo da história pessoal. Bancário desde os 18 anos na mesma instituição financeira em que estagiara a partir dos 14 . Lembrou de quando, conduzido por sua mãe à agência do banco em sua cidade, no interior do Estado, conseguiu-lhe um emprego de meio turno, para continuar estudando.

De fato, ele não tinha muita escolha: o emprego era importante, pois sua família era muito pobre. Penúltimo de sete filhos, seu pai era biscateiro, e como gostava de bebida e jogos de cartas, por vezes gastava o pouco ganho em bares e carteado. $\mathrm{O}$ paciente relatou assistir, vez ou outra, à distância, os jogos, a mando da mãe, com a missão de confiscar o dinheiro antes que o pai novamente o perdesse (o que resultava numa espera demorada e humilhante): Gregório contemplava os jogadores como se fossem de um mundo diferente do seu, mas que lhe atraía por ser masculino e representar uma diferença do mundo doméstico, materno. Essa diferença esvaiu-se durante a adolescência de Gregório, quando seu pai separou-se da mãe e passou a viver com outra mulher, com quem teve outros filhos.

Sua mãe, que se mostrava infeliz e amargurada no casamento, trabalhava como professora do Ensino Fundamental, sendo a fonte segura do sustento. Ainda fazia trabalhos manuais, para completar o dinheiro mensal. $\mathrm{O}$ fato de ter gerado sete filhos com aquele homem parecia sugerir que ela, de algum modo, gostava dele, com quem provavelmente matinha uma relação ambivalente - quiçá, na posição masoquista, que se invertia quando se relacionava com os filhos. Trabalhava muito, chegava cansada em casa, chorava e com frequência ficava furiosa, descarregando sua ira em surras que dava nos filhos, até cansar. O paciente não era exceção: tanto apanhava quanto via os irmãos apanharem.

Essa mulher ainda era devota, católica que gostava de encomendar a si e a família a Deus, frequentando regularmente a igreja (numa religiosidade que, como se pode imaginar, não chegou a contagiar Gregório: ele tinha fé, mas não religião quando chegou à análise). Quando o pai do paciente saiu da casa da mãe, esta assumiu definitivamente a função que, na maior parte das vezes, já exercia, como provedora da família, exercendo uma influência controladora e autoritária, literalmente violenta.

Sobre seus três irmãos homens, todos mais velhos, sabia-se que o mais velho, tendo migrado para o Sudeste, obtivera relativo sucesso, mas estava longe demais para ter-se certeza disso. Os outros dois bebiam como o pai, sustentados por suas respectivas mulheres. O imediatamente mais velho fora alguém importante em sua vida: durante sua infância e adolescência, o paciente foi iniciado sexualmente por esse irmão, que sempre penetrava Gregório, machucando-o. Nem por isso, desgostava de seus irmãos: mesmo aquele que o usara sexualmente era apreciado, como o pai negligente, numa afetividade ambígua, sendo correspondido pelos irmãos.

Diferente do ramo masculino de sua família, Gregório saíra-se bem na escola e chegou à universidade, em que começava uma licenciatura na área das Humanidades, o que, se não interessava diretamente a seu trabalho como bancário, já lhe daria condições de pleitear, mais à frente, avanços na empresa.

Por força da sua proximidade com as irmãs (uma bem mais velha, que ajudara a mãe a criá-lo, a outra bem próxima dele) e pela presença da mãe na casa, tinha companhias mais frequentemente femininas que masculinas: com o tempo, após a irmã (pouco) mais nova que ele se ter oferecido para iniciá-lo sexualmente, na adolescência, elas souberam de sua orientação sexual, sem que ele àquela altura se sentisse rejeitado por elas.

Ele era, portanto, um jovem motivado para o tratamento e com boas razões para iniciá-lo. Porém, alegou não poder custeá-lo, pois, já morando sozinho na capital, continuava a ajudar a mãe, enviando-lhe parte de seu salário. Já ao final da sessão, o analista colocou-se à disposição para um eventual recomeço, quando fosse possível e, assim, sem interferir na relação com a mãe, conseguiu resguardar seu lugar, medida essencial para preservar o que se sucederia, para suportar transferências marcadas por vários enigmas, inclusive o paterno - no que ele depois passou a ver em mim da indiferença ou da virilidade do pai que o abandonava, ou do irmão que dele abusara sexualmente. 
Um detalhe importante, ainda, fez ver ao analista a força dessa primeira entrevista - suficiente para manter Gregório desejando voltar: o paciente mostrou uma foto recente em que se mostrava forte, talvez até mesmo pretendendo ser sedutor - testando, desde logo, a firmeza do enquadre, no que nele ele já supunha haver de interdito -, ao mesmo tempo em que me introduzia, simbolicamente, na casa de sua infância.

$\mathrm{O}$ analista, mantendo-se em seu lugar ambivalente de destinatário do enigma inconsciente do paciente, mas também de suporte para a fantasia, garantiu um enquadre que, desde o início, no caso de Gregório, permitiu o desejo e sua interdição. Dera-se a primeira cena, ao mesmo tempo preenchida de sedução e vazia: como na temporalidade retroativa do psiquismo (Maia \& Andrade, 2010), o que sucede a uma sessão pode modificar, inclusive, o que já passou, mas ficou depositado no inconsciente.

\section{NA VIDA E NA TRANSFERÊNCIA, FANTASIAS MASOQUISTAS}

Somente um ano depois, Gregório retomou o contato e começou a análise. Pelos dois anos seguintes, o paciente resistiu às regras e à rotina da análise: não queria aceitar uma segunda sessão. Além disso, proporcionalmente, foram esses os anos em que ele mais faltou à análise. Essas faltas não chegavam a ameaçar o enquadre, mas sugeriam a evitação, característica dum esforço ambíguo por manter seu espaço e dele se afastar para provocar o analista, expressando, inconsciente e passivamente, sua agressividade.

Ademais, criava obstáculo ao pagamento de sessões em que havia faltado, o que levava o analista a insistir no pagamento da dívida e a indicar-lhe que nesse comportamento haveria a repetição que deveria ser falada, no sentido, por exemplo, de avaliar se o analista ser-lhe-ia indiferente, como seu pai na infância.

De fato, garantir o enquadre exigiu que o analista ao contrário da mãe de Gregório - não batesse nele, mas que tampouco se omitisse, como o pai, mesmo quando provocado (pois, àquela altura, era raiva o que ele queria provocar, ao desafiar regras inegociáveis da relação analítica, o tempo e o dinheiro). Havia a atualização, na cena transferencial, de outras cenas vividas com a mãe sádica e o pai narcisista e negligente.

A mais forte dessas cenas que conseguiu lembrar consistia nas surras a que assistia ou levava: ele se lembrava da mão materna a segurar seu pulso, enquanto ele corria em círculos à volta dela e apanhava sem parar, até que ela arfasse de cansaço (“como se tivesse gozado", pensei). Depois, deitada na rede, ela o chamava (e a qualquer outro) e repetia um ritual, em que dizia algo como: "Você não sabe que eu lhe amo? Eu bati em você, mas a culpa é sua. Se você não me desse motivo, eu não batia”. E as juras maternas, disfarçadamente arrependidas, a um só tempo histéricas (já que as surras substituíam a cópula) e sádicas (já que mantinham a responsabilidade da violência sobre o alvo indefeso, as crianças), eram acompanhadas de beijos e abraços.

Vários elementos dessa cena real podem ser analisados: destacam-se o esquecimento parcial do corpo materno (a imagem fixa a mão materna) no momento do espancamento, a que se segue a memória da mãe inteira, no segundo tempo (do carinho na rede); o comprometimento da própria mensagem materna, aqui inferida pelo comportamento e pelas palavras da mãe quando espancava e após o espancamento: ela provavelmente substituía o homem pelos filhos e invertia sua passividade erótica na atividade violenta contra as crianças, prestando-se como modelo de um sadismo que ajudou a imprimir, no psiquismo de Gregório, a fórmula freudiana de 1919 (Freud, 1919/1974d), aqui parafraseada: "minha mãe bate em mim porque me deseja".

Fortemente enraizado no psiquismo de Gregório, esse traço narcísico - manifesto no seu comportamento que, numa linguagem psicológica, seria nominável como "passivo-agressivo" (American Psychological Association, 2010, p. 689) e, na terminologia psicanalítica, como sadomasoquista serviu-lhe como proteção contra uma desorganização psíquica mais séria. Nesse sentido, o masoquismo originário - no sentido que lhe atribui Laplanche (1992/2008b) - em Gregório foi elaborado pela capacidade de fantasiar narcisicamente. Em outras palavras, o menino aprendeu, desde cedo, a "fazer do limão a limonada", a reverter a experiência dolorosa em exercício para suportar, sem se deixar desmanchar, o desamparo em face de uma mãe que irrompia o cotidiano para espancar os filhos; e diante de um pai irresponsável. É claro, não se pretende que a cena da surra materna fosse a originária nem, certamente, a única.

Gradativamente, ao final do segundo ano o vínculo de confiança com o analista começava a suplantar a agressividade manifesta, concomitantemente ao estabelecimento de vínculos amorosos mais estáveis com alguns namorados. Nesse contexto, a recorrente atuação de sua fantasia erótica, constitutiva de outra cena, esta muito mais perigosa, angustiou o analista a ponto de ser necessário intervir. No início do terceiro ano de análise, admitiu que seu comportamento sexual com frequência almejava a consumação de uma cena: experimentando uma enorme angústia, punha-se a 
procurar, fosse de dia ou de noite, homens para um encontro casual.

Mas não qualquer homem desconhecido: seus parceiros de um único encontro deveriam corresponder ao estereótipo do machão de baixa renda, grosseiro e convencido, deselegante, que fizesse sexo com outros homens, mas não se considerasse homossexual, por ser sempre quem penetrava (atividade essa associada ao homem da relação). Essa fantasia incluía injúrias profundamente humilhantes durante o sexo, que sempre deveria consumar-se por uma penetração dolorosa de Gregório e uma separação fria. Em seguida, o paciente experimentava uma tranquilidade recompensadora e intensa, que se espraiava por algumas horas. $\mathrm{O}$ paciente jamais penetrava seus parceiros nessas cenas, cujo roteiro exigia a passividade e a submissão extremas e arriscadas.

Com efeito, cenas com esse roteiro para o sexo furtivo tornaram-se cada vez mais recorrentes. Gregório inicialmente mencionava fazer sexo com o porteiro do prédio em que ele morava, com o vigia da farmácia próxima ao prédio em que se situava o meu consultório, e até com o porteiro do prédio do meu consultório. Além do fato de ter múltiplos parceiros sexuais, relatou que com todos eles fazia sexo anal sem qualquer proteção. Muitas dessas ocasiões foram decorrentes da angústia experimentada nas sessões (no caso, os porteiros eram os apoios mais úteis à fantasia)!

Não é de se admirar, também, que, num contexto de homofobia alimentada pelo machismo de seus parceiros e pela reconhecida posição de superioridade financeira de Gregório, alguns homens que o paciente encontrava nos recantos da cidade velha se sentissem à vontade para adotar práticas moralmente perversas: fora da cena fantasiada, o paciente era fisicamente agredido, tinha dinheiro e pequenos objetos roubados.

Algumas sessões após o Carnaval de 1995, antes mesmo de admitir que praticava sexo anal, em que sempre era penetrado, sem preservativo, Gregório relatou ter corrido risco iminente de morte no período da folia: saíra à noite, no centro da cidade, com um homem que, após ter concluído o sexo, buscando roubá-lo, pôs em sua cabeça uma arma e o ameaçou, dizendo que o mataria naquele instante. $\mathrm{O}$ paciente, apavorado, entregava tudo ao ladrão, enquanto ouvia expressões homofóbicas bem conhecidas. Gregório chorava e pedia para ser poupado, invocando, como um menininho amedrontado, a sua mãe. De acordo com Gregório, foi o chamado à mãe que, nas palavras do bandido, o teria salvado: este último saiu do quarto rapidamente, deixando o paciente com a roupa do corpo.
Em que pesassem o enorme risco e a ambivalência do comportamento do paciente, a paz com que a cena se consumava, própria do Nirvana, foi entendida na perspectiva do gozo narcísico: uma vez terminado todo o ritual, não haveria mais que desejar. Além desse desejo de autonomia (Maia, 1997), verificou-se tanto a repetição da fantasia sadomasoquista estruturada com a mãe quanto à atuação repetida do desejo pelas figuras masculinas e, não muito distante delas, pela figura do pai, idealizada na fantasia erótica.

A idealização desse pai, aliás, tinha uma clara função defensiva, facilitada também pelo investimento libidinal ao objeto masculino. $\mathrm{O}$ pai real, bem diferente do fantasiado, dava sinais da própria perversão: silenciosamente, se exibia como o jogador bon vivant, cujos traços facilmente se podiam ver reproduzidos naqueles homens com quem Gregório buscava a pacificação de sua angústia - como, na infância, era obrigado a esperar, passiva e demoradamente, pelo dinheiro que seu pai só vez ou outra lhe entregaria, a mando de sua mãe, de quem o paciente funcionava como extensão.

Ao dirigir-se a interpretação da cena fantasmática também para o pai, ressalta-se o que o mundo masculino pôde deixar de marcas conscientes ou préconscientes na subjetividade daquele paciente. Pois ele não era enviado pela mãe a assistir às cenas dos jogos, às bebedeiras, aos excessos paternos? Pois ele não via a mãe, tão terrível, dobrar-se àquele homem, que sempre parecia tão periférico? A tradução do enigma sexual contido e atualizado na cena do sexo com os homens não só retoma a exposição à mãe, mas a entrega ao pai, tão reconstituído pela fantasia quanto, por causa disso, desejado.

Esse pai, quase tão marginal como os bandidos rudes com que o paciente saia, no triângulo edípico foi visto o suficiente por Gregório, tanto direta quanto indiretamente (pelo olhar materno), para que chegasse a fazer, ao menos imaginariamente, no plano da fantasia, uma pequena diferença. Gregório nem sempre ou obrigatoriamente se punha no lugar da sua mãe, esperando angustiada por seu homem: ele repetia, na sua fantasia, o encontro com o pai que, mesmo precariamente, ainda o pode salvar do assédio materno - um pai interno, nunca é demais lembrar, um homem que, além de objeto, também (prioritariamente, aliás) foi emissor de mensagens sexuais. E se a mãe, diante do pai, sugeria versões do masoquismo, o pai, por sua vez, como suposto nãocastrado já genital, como masculino, insinua, mais que a alternativa sádica, a saída narcísica!

Um sonho do paciente, relatado seis meses após essa cena em que quase morreu, resume bem o traço narcísico e idealizado da imago paterna: 
Via um menino que meu pai hoje cria, juntamente com a prostituta velha com quem está casado. O menino atraía a atenção do pai enquanto ele jogava. Meu pai se voltava para o menino e eu via o pênis do pai: o membro parecia volumoso e redondo, como um gato (09 de agosto de 1995).

O paciente associou as características do pênis paterno às reclamações que o pai fazia para entregar o dinheiro ganho no jogo. Disse que o menino do sonho recebia uma atenção que Gregório nunca teve. Ao falar isso, teve raiva da mulher que o afastou de seu pai; do pai, por pensar, bem ou mal, nele, desejando-o.

Se analisado pelas pistas associativas do paciente, alguns elementos da perversão paterna saltam aos olhos: a cena é habitual e Gregório a assiste impotente, como no passado. Nela, o menino é situado na cena apenas como um meio para um terceiro observador enxergar o pênis paterno, grande e intumescido ereto, talvez. Como num jogo, a atenção dada ao menino era um blefe para que o jogador exibicionista mostrasse seu sexo, para exercitar à distância seu poder de iludir. Com suas gordas e macias reclamações, semelhantes a um gato bem nutrido, o pai de Gregório era associado à despreocupação, à sensualidade, à esperteza e à liberdade. Seu pênis-gato era o símbolo do egoísmo e da autossuficiência paternas, da aparente indiferença para com o filho.

Re-encontrar-se com vários homens que o penetram é, por eles, entregar-se não só à capacidade de suportar sofrimento, dor, humilhação, mas também exercitar as capacidades imaginárias desse homem que não precisa de ninguém - que pode até fazer sexo com outro homem, mas que não é homossexual; que pode até perder sucessivas vezes no jogo, mas que não é um derrotado; que pode até dormir com uma mulher (ou com várias), mas que não se apaixona por nenhuma delas.

Não se trata aqui de presumir um caminho narcisista que possa dispensar, de fato, o problema posto pela diferença anatômica entre os sexos. Um narcisismo assexual, metapsicologicamente falando, é inviável. Afirma-se que, pela defesa narcísica, a genitalidade ganha $\mathrm{o}$ estatuto que lhe atribui $\mathrm{o}$ masoquismo (e o sadismo): o de parcialidade, pois o masoquismo é o tempo primeiro do auto e o segundo tempo do humano (Laplanche, 1968/2008a, 1992/2008b), precedendo, pode-se dizer, a genitalidade, relativizando-a.

\section{QUANDO A CENA TRANSFERENCIAL TRADUZ A CENA FANTASMÁTICA}

Foi, portanto, no início do terceiro ano de análise que o analista interditou aquela atuação sexual que parecia intocada pela análise, entrando nas sessões sob a forma de relatos que pareciam provocações, sobretudo porque não continham uma questão. $\mathrm{O}$ comportamento erótico de Gregório já não mais era apenas sintoma, mas, desde que incluído na análise, era atuação sexual, nos moldes do que entende Laplanche (1987/1993).

Assim sendo, gradualmente a fantasia erótica atuada em conduta de altíssimo risco foi interpretada como um esforço de Gregório para que a cena fantasiada se concretizasse no setting: completando o par sadomasoquista que instaurou o desafio - "quanto mais eu apanhar, mais amado por (e menos dependente de) quem me bate serei". Caso parecesse indiferente ao perigo que ele corria (como imaginariamente poderia fazer o pai) ou demonstrasse um interesse ambíguo e carregado de irritação e ódio, (como poderia agir a mãe), o analista cairia na armadilha do curto-circuito fantasmático.

A própria situação era delicada: não parecia haver intervenção (ou interdição) que estivesse isenta da possibilidade de ser tragada pela fantasia - mesmo a mensagem "façamos análise" poderia ser recebida como "obedeça-me e me faça feliz": com a proibição de repetir a fantasia e com o imperativo de falar sobre ela em análise, o analista poderia perfeitamente ser associado à mão que batia até cansar.

Uma diferença, porém: Gregório não sabia se o analista gozava com aquilo tudo. Havia, portanto, a chance de retomar-se o processo tradutivo a ponto de que novos pensamentos, menos autodestrutivos, viessem à tona. Uma vez reinstaladas as condições da SAF pelo setting analítico, as antigas traduções dos enigmas parentais, responsáveis por forjar as fantasias eróticas de Gregório, a ponto de ameaçar sua autoconservação, abrir-se-iam, a partir desse enquadre (cujo cerne é a transferência), a novas formulações, menos patológicas. Havia a esperança de que novas (e melhores) significações aparecessem, no sentido que Laplanche (1987/1993) atribui à transferência.

Numa espécie de recomeço (a regra fundamental fora anunciada no início do processo, afinal!), arriscando-se a perder o paciente, em nome de seu próprio bem-estar, o analista pensou em pôr um limite àquele estado de coisas.

$\mathrm{O}$ analista comunicou a Gregório sua hipótese em linhas gerais e o avisou de que, caso continuasse a concretizar suas fantasias assim, não poderia mais atendê-lo, visto que tanto arriscava a própria vida e a dos outros (podendo contrair e transmitir facilmente o HIV) quanto deixava de falar da angústia que transformava em ação, repetindo seu aprisionamento patológico. $\mathrm{O}$ analista não estava disposto a acompanhar um suicida em potencial, naquelas condições e finalidades. A única saída daquele padrão 
autodestrutivo seria obedecer à regra fundamental e falar na sessão o que viesse à cabeça e fosse por ele ali experimentado - inclusive, é óbvio, o que aparecesse de excitante ou angustiante.

O paciente respondeu-me que seria difícil, mas que tentaria. Comprometeu-se a não mais se expor como fazia, a falar dos problemas em cumprir essa promessa. Realmente, não só ele investiu na promessa, como o fez de modo intenso e, doravante, mais positivo (do ponto de vista do que Freud denomina por transferência positiva): passou a ter duas, eventualmente até três sessões semanais. Em 1998, a mesma quantidade de sessões, mantendo o mesmo ritmo de sua psicanálise. Confirmou-se aquilo a que se refere Laplanche (1992/2008c, p. 433), que afirma ser a análise uma ocasião de "reabertura da dimensão da alteridade".

Após quase três anos de repetição e alguma recordação, Gregório começou a elaborar um conteúdo, inclusive por meio de sonhos. Dois deles apresentados como sendo produzidos na mesma noite anterior - e suas respectivas associações livres sugeriram que o paciente processava, em seu ritmo, o efeito da proibição de levar a cabo as fantasias masoquistas. No primeiro,

\begin{abstract}
"Voltava para casa, ia almoçar antes de trabalhar no banco. Passando por um restaurante self-service, sem querer entrar, inicialmente, olhei, gostei e fiquei. Ao ser mal servido por uma moça que lhe lembrou uma garçonete protestante de uma lanchonete na universidade em que estudava, foi reclamar com o avô dela, que aparentou neutralidade, mas ficou do lado dela, afirmando não quererem mesmo muita clientela e não ser aquela uma hora (meio-dia) de pique. Repeti o prato" (sonho 1).
\end{abstract}

"Saindo do restaurante, descobri três marginais, um deles negro, que roubavam a casa vizinha ao restaurante, de propriedade do dono do restaurante (que só descobre o roubo à noite). Preocupei-me em delatar os marginais, para não ser confundido com um deles, após a discussão no restaurante com o avô da moça (proprietário do empreendimento e da casa). Fui depois perseguido pelos marginais delatados, que me queriam fazer mal"' (sonho 2).

Ao associar, Gregório observou que a garçonete parecia-lhe atraente, era rígida como um homem; o avô, também rígido, parecia um dirigente do banco em que trabalhava. O restaurante foi associado ao banco e os marginais ao próprio desejo homossexual.
Em sua interpretação, o analista considerou, além das associações, a observação que Gregório fizera na sessão imediatamente anterior: após falar de uma imagem idealizada de homem que queria ter para si, ele, que não se sentia bem com sua orientação, se perguntara por que era homossexual, queixando-se contra o pai - que não o poderia condenar, já que abandonara a casa - e contra a mãe - a quem responsabilizou pela repressão de sua tentativa, durante a adolescência inicial, de namorar garotas.

O sonho do paciente, com a bela metáfora do alimento, é paradigmático, condensando e deslocando seus principais conflitos, e permite entrever a identificação ambígua com o feminino - que tende para o masculino (a moça tem atributo associado ao masculino, à rigidez) - e o desejo de proteção por uma imago ao mesmo tempo paterna e masculina (o avô, homem mais velho), diante do mal-estar provocado pela figura feminina. $\mathrm{O}$ self-service que o paciente melhor conhecia era o de seu esquema erótico masoquista, de fundo narcísico, em que ele, sem precisar das relações típicas a um restaurante à la carte, podia alimentar-se quase sem recorrer ao outro e, claro, sem ter de pagar preços mais altos, inclusive os afetivos e sexuais. O sonho, nesse "sem querer entrar" inicial, seguido de "olhei, gostei e fiquei", resume o compromisso com a interdição acordada com o analista e a realização desse desejo (afinal, ele gosta, fica, come, repete o prato!).

Porém, Gregório foi além de sua compulsão à repetição, indicando que a interdição também funcionou como dispositivo para iniciar-se uma metábole, uma transformação das mensagens enigmáticas em torno das quais estruturara seu masoquismo: por sentir-se mal atendido por uma mulher, dirige-se a um homem e a ele dela reclama. $\mathrm{O}$ Édipo do paciente aí aparece, realizando-se uma cena que, na vida real, nunca se deu: queixar-se ao pai dos destemperos maternos, ou, simplesmente, ser protegido por ele.

E o que se renova? A mensagem enigmática paterna: aparentemente neutro, o avô apoia a moça, sua neta, desmerecendo a importância do freguês, que chega em momento desinteressante ou inapropriado. Como quando menino, ao agir como espião e guarda materno junto ao pai jogador, Gregório foi tratado com desconsideração pelo dono do restaurante (no deslocamento, o gerente do banco em que trabalhava e, na interpretação, seu próprio pai). Apesar disso (ou até por causa disso), repete-se o prato.

A vingança narcísica é perpetrada: Gregório manda os ladrões de seu desejo homossexual assaltarem a casa do avô/dono do restaurante/gerente do banco/homem das riquezas e do poder/dono do falo/pai. Se ele, aparentemente neutro, posiciona-se 
em favor de quem trata mal o paciente, terá sua paga, inclusive simbólica (o avô só descobre o roubo à noite, tarde demais). Com essa expressão sádica de sua sexualidade (o roubo), sempre tratada na cena fantasmática como marginal (a pergunta magoada e queixosa, em relação ao pai e à mãe, do paciente: "por que justamente eu tinha de ser o marginal, condenado por desejar homens?"), o masculino é, em parte, depauperado de sua posição imaginariamente fálica.

Com o Narciso masoquista, antes humilhado e agora reparado, passa-se, evidentemente, à culpa e à autopunição: Gregório teme ser confundido com um dos marginais, temendo que sua sexualidade traia sua fantasia de poder ter todos os homens sem qualquer risco, para poder, como um jogador, a seu modo, sentar-se à mesa (não mais do alimento, mas da jogatina) e participar daquele secreto prazer que reunia tantos homens juntos, por tantas horas e com tantas emoções, excitando seu pai.

No sonho, ressalte-se, a sexualidade que aparece é bem mais polimórfica que genital, e entendi que ambas serviam, afinal, ao mesmo objetivo marginal: possuir os bens paternos, tomar, ainda que furtivamente (como um ladrão a que se assemelha, e de que se aproxima, pela marginalidade), aquilo que ele não dá em público e com prazer, para reconhecer a importância (narcísica, afinal) desse filho.

Gregório denuncia os ladrões e é por eles perseguido. Os desejos marginais (mais que homossexuais, no sentido sexológico de uma orientação) o atacam, atacam a solução que ele encontrara para fazer-se reconhecido, protegido pelo dono do restaurante/gerente do banco/pai. E que desejos são esses? O seu caráter homossexual, a que o paciente refere-se na associação, aponta para a orientação sexual, é certo, mas, sobretudo, indica sua origem interna: são seus desejos, já não mais os de alguém que o pega de assalto para espancá-lo. E dos próprios desejos, quem pode escapar?

A pergunta pelo próprio desejo era relevante, do ponto de vista narcísico, mais até que do ponto de vista genital. Isso porque a homossexualidade de Gregório encaminhava-o para os homens, mas sua fantasia, para certo tipo de homem, rude como o pai e, no sonho, também ladrão (um dos gatunos é negro como o pai do paciente) - diante de quem não há risco de vir a ser desejado ou, por consequência, de depender.

A imago do analista parece, também, incluir-se na sequência masculina iniciada pelo avô: este aparenta ser neutro, mas toma partido (pela neta). Em contexto transferencial, o paciente poderia estar a dizer: "sim, o service não é tão self assim, afinal... Mas você me paga, por não me ter deixado à vontade, por ser um homem a quem eu não posso ter e que ainda me proíbe de brincar lá fora!..." Repete-se o prato, ele volta a cada sessão, semana após semana, mas se sente maltratado, pois sua fantasia está ameaçada pela análise. As resistências, naturalmente, não sumiam no ar como por encanto, e o não poder servir-se sozinho, em paz, no self-service que a análise fora até antes da interdição muitas vezes comparável provocava também queixumes contra o analista e a análise!

A paga da vingança contra mim pairava no ar, sessões após esse sonho, quando o paciente buscava saber quem seu analista desejaria. Essa curiosidade ia e vinha, e Gregório admitiu: só se o analista fosse heterossexual poderia ajudá-lo. Se fosse homossexual, seria igual a ele. Na cena da análise agora, a partir do roteiro transferencial, atualizava-se o enigma da sexualidade, tanto em seu caráter de passividade inicial quanto de reação masoquista e narcísica.

A pergunta sobre o que queria seu analista é uma derivação de outra, assim formulável: "o que quer de mim esse analista, o que ele é capaz de fazer comigo?". Nessa sequência, tem-se a simetria com os três momentos analisados por Freud (1919/1974d): num nível manifesto, o da pergunta pela minha orientação sexual, a neutralidade narcísica ("ele quer algo"); num nível mais inconsciente, a passividade masoquista ("de mim"); também inconsciente, detrás da solução narcísica, o desejo objetal ("eu o desejo").

Ora, um homem homossexual desejar um heterossexual é um contrassenso que só se justifica no plano inconsciente da solução masoquista e narcísica para o enigma da sexualidade. Em tese (e a fantasia vive de idealizações), o homem heterossexual não só tem os atributos fenotípicos e culturais do gênero masculino, como corresponde a eles: é superior a todos (à mulher, nessa fantasia, e a tudo que for castrado) e deles não precisa. É, todo, autossuficiente - tanto que é requisitado, é necessário, é, como no sonho do paciente, o dono do restaurante a dizer: "vire-se, se não estiver satisfeito, porque eu nem lhe quero mesmo como freguês, você não veio na hora do (meu) pique". Num deslocamento linguístico, o pique tanto faz apelo ao termo que, na linguagem chula, representa o pênis, quanto sugere que o homem heterossexual não está, diante de Gregório, excitado, no pique dos seus desejos (que, por serem heterossexuais, estavam, de saída, voltados para a mulher). $\mathrm{O}$ masculino, assim reduzido à sua expressão heterossexual, evocava na história de Gregório o seu pai e seu irmão mais velho (que o iniciara sexualmente e que terminou casado).

Leia-se, nessa atribuição imaginária ao dono do restaurante/gerente de banco/pai/homem: "você não é mesmo o objeto que eu prefiro (pois eu gosto mesmo é de mulher), só me serve para eu gozar, não para eu desejar". O homem heterossexual, nessa fantasia de 
traços evidentemente masoquistas (querer uma pessoa que não quererá de volta), representa tanto o ativo superior quanto o bem acabado narcisicamente, que não entra na negociação sexual com a moeda do desejo a alguém, porque seu fim é outro - manter-se desejando a si mesmo. A imagem do heterossexual que faz sexo com um homossexual consumava, assim, para Gregório, sua fantasia de onipotência, comunicada, breve e parcialmente, aquele dentro de quem fosse posto o pênis ereto e despejado o esperma. $\mathrm{E}$ a simples possibilidade de que eu funcionasse assim, nessa fantasia, garantia, provisoriamente, meu lugar no imaginário erótico do paciente e, com ela a transferência e uma energia considerável para a análise.

\section{OS ANOS FINAIS DA ANÁLISE: NOVAS RESPOSTAS PARA UM ENIGMA REINSTALADO}

Se a análise de Gregório pretendia intervir em favor da vida, foi então que a vida interveio em favor da análise do paciente: após várias tentativas com outros namorados (frustradas, inclusive, por sabotagens do próprio paciente) e ainda com muita relutância em face da proximidade do outro, o paciente apaixonou-se por Donato — pseudônimo de um homem um pouco mais velho que o analisando, com quem passou a relacionar-se em fins de 1998 e por quem foi correspondido, sexual e afetivamente.

Donato residia em outro Estado e Gregório, já findo seu curso, agarrou a possibilidade de crescer no trabalho, aceitando uma promoção que o levou a mudar-se para a cidade de Donato. O paciente adotava, então, um perfil profissional mais ativo, sua agressividade tornara-se melhor empregada e ele começou a ser reconhecido.

Gregório mudou-se, então, mas quis manter a análise, que, evidentemente, se viu gradualmente afetada no número de sessões. O paciente discutia suas dificuldades decorrentes da nova vida: morava com Donato, ainda sentia desejos de fazer sexo aleatoriamente, mas pesavam sobre esses desejos os sentimentos pelo namorado, seu compromisso com um homem que também se comprometera com o paciente.

Estava claro que Gregório ainda temia amar um homem castrado (cuja dependência amorosa, naturalmente, evidenciava-se na relação), porque a posição castrada, para ele, estava inconscientemente sempre associada à mulher e ao masoquismo. Amar sem tanto sofrimento era uma fórmula custosa, mas já crível para o paciente.

Recebendo a indicação de nomes de outros psicanalistas na cidade de sua nova residência, Gregório reconheceu, na entrevista com o primeiro que buscou, um homem que vira algumas vezes em saunas daquela capital, muito antes de apaixonar-se por Donato. Nunca tinham feito sexo um com o outro, mas não só o desejo do outro analista parecera evidente a Gregório, como o reconhecimento impossibilitou que o paciente pudesse falar disso para ele. A sessão com meu colega, relatada por Gregório, foi inócua e o paciente não mais retornou àquele colega.

Gregório, que aceitou continuar sua análise com uma mulher, viveu, no (des)encontro com aquele colega, o risco imaginário de não ser desejado por quem, em tese, poderia desejá-lo genitalmente, como objeto total e foi novamente mobilizado por conteúdos inconscientes associados a restos não-simbolizados de mensagens parentais. O desejo do outro (profissional), uma vez identificado, estava próximo demais para que o estrangeiro interno parecesse ainda mais ameaçador, fora de controle. O fim de uma análise de Gregório foi, portanto, marcado pela reabertura do seu enigma sexual. Nada de surpresas, mesmo assim, pois se sabe, com Freud e Laplanche, que o inconsciente refaz-se em passagens derivadas da reabertura dos enigmas e da recriação do sexual.

\section{REFERÊNCIAS}

American Psychological Association - APA (2010). Dicionário de Psicologia. (Daniel Bueno, Maria Adriana Veríssimo Veronese \& Maria Cristina Monteiro, Trad.). Porto Alegre: Artmed.

Freud, S. (1974a). Carta 69. In J. Strachey (Ed. e J. Salomão, Trad.), Edição Standard Brasileira das obras psicológicas completas de Sigmund Freud. (Vol. 1, pp.279-281). Rio de Janeiro: Imago. (Original redigido em 1897).

Freud, S. (1974b). Três ensaios sobre a teoria da sexualidade. In J. Strachey (Ed. e J. Salomão, Trad.), Edição Standard Brasileira das obras psicológicas completas de Sigmund Freud. (Vol. 7, pp.123-253). Rio de Janeiro: Imago. (Original publicado em 1905).

Freud, S. (1974c). Os instintos e suas vicissitudes. In J. Strachey (Ed. e J. Salomão, Trad.), Edição Standard Brasileira das obras psicológicas completas de Sigmund Freud. (Vol. 14, pp.137-168). Rio de Janeiro: Imago. (Original publicado em 1915).

Freud, S. (1974d). Uma criança é espancada - uma contribuição ao estudo da origem das perversões sexuais. In J. Strachey (Ed. e J. Salomão, Trad.), Edição Standard Brasileira das obras psicológicas completas de Sigmund Freud. (Vol. 17, pp.225-258). Rio de Janeiro: Imago. (Original publicado em 1919).

Freud, S. (1974e). Além do princípio de prazer. In J. Strachey (Ed. e J. Salomão, Trad.), Edição Standard Brasileira das obras psicológicas completas de Sigmund Freud. (Vol. 18, pp.17-90). Rio de Janeiro: Imago. (Original publicado em 1920). 
Freud, S. (1974f). O problema econômico do masoquismo. In J. Strachey (Ed. e J. Salomão, Trad.), Edição Standard Brasileira das obras psicológicas completas de Sigmund Freud. (Vol. 19, pp.199-216). Rio de Janeiro: Imago. (Original publicado em 1924).

Laplanche, J. (1988a). Da teoria da sedução restrita à teoria da sedução generalizada. In: J. Laplanche. Teoria da Sedução Generalizada e outros ensaios (pp. 108-125). (Dóris Vasconcellos, Trad.). Porto Alegre: Artes Médicas.

Laplanche, J. (1988b). A pulsão de morte na teoria da pulsão sexual. In: J. Laplanche. Teoria da Sedução Generalizada e outros ensaios (pp. 97-107). (Dóris Vasconcellos, Trad.). Porto Alegre: Artes Médicas.

Laplanche, J. (1992). Novos fundamentos para a psicanálise. (Cláudia Berliner, Trad.). São Paulo: Martins Fontes. (Original publicado em 1987).

Laplanche, J. (1993). A tina. A transcendência da transferência. (Paulo Neves, Trad.). São Paulo: Martins Fontes. (Original publicado em 1987).

Laplanche, J. (2008a). La position originarie du masochisme dans le champ de la pulsion sexuelle. In: J. Laplanche. La révolution copernicienne inachevée (1967-1992) (pp.37-58). Paris: Presses Universitaires de France. (Original publicado em 1968).

Laplanche, J. (2008b). Masochisme e Théorie de la Séduction Généralisée. In: J. Laplanche. La révolution copernicienne inachevée (1967-1992) (pp. 439-456). Paris: Presses Universitaires de France. (Original publicado em 1992).

Laplanche, J. (2008c). Du transfert: sa provocation par l'analyste. In: J. Laplanche. La révolution copernicienne inachevée (1967-1992) (pp.417-456). Paris: Presses Universitaires de France. (Original publicado em 1992).

Maia, L. M. F. (1997). O desejo de autonomia à prova de uma formação masoquista. Psicanalítica, n. 5, p.45-61.

Maia, L. M. F., \& Andrade, F. C. B. (2010). Nachträglichkeit: leituras sobre o tempo na metapsicologia e na clínica. Estudos de Psicanálise, 33, p.75-90.

Menezes, M. C., \& Passos, A. (1972). Mora na filosofia. Intérprete: Caetano Veloso. In Caetano Veloso. Transa. Rio de Janeiro: Polygram. 1 LP. Faixa 6.

Recebido em 19-07-2012 Aceito em 22-11-2012
Endereço para correspondência:

Fernando Cézar Bezerra de Andrade. Av. Epitácio Pessoa, 753 - Sala 809, Bairro dos Estados, CEP 58030-904, João Pessoa-PB, Brasil.E-mail: frazec@uol.com.br. 